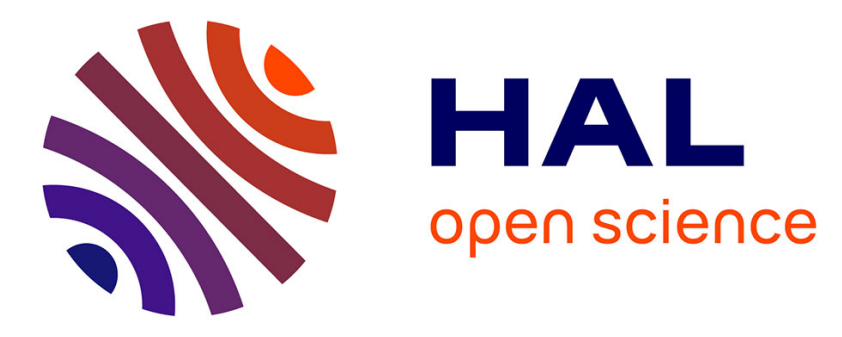

\title{
Pulsatile cerebrospinal fluid and plasma ghrelin in relation to growth hormone secretion and food intake in the sheep.
}

\author{
Dominique Grouselle, Elodie Chaillou, Alain Caraty, Marie-Thérèse \\ Bluet-Pajot, Philippe Zizzari, Yves Tillet, Jacques Epelbaum
}

\section{To cite this version:}

Dominique Grouselle, Elodie Chaillou, Alain Caraty, Marie-Thérèse Bluet-Pajot, Philippe Zizzari, et al.. Pulsatile cerebrospinal fluid and plasma ghrelin in relation to growth hormone secretion and food intake in the sheep.. Journal of Neuroendocrinology, 2008, 20 (10), pp.1138-46. 10.1111/j.13652826.2008.01770.x . inserm-00314040

\section{HAL Id: inserm-00314040 https://www.hal.inserm.fr/inserm-00314040}

Submitted on 20 Dec 2008

HAL is a multi-disciplinary open access archive for the deposit and dissemination of scientific research documents, whether they are published or not. The documents may come from teaching and research institutions in France or abroad, or from public or private research centers.
L'archive ouverte pluridisciplinaire HAL, est destinée au dépôt et à la diffusion de documents scientifiques de niveau recherche, publiés ou non, émanant des établissements d'enseignement et de recherche français ou étrangers, des laboratoires publics ou privés. 
Pulsatile CSF and plasma ghrelin in relation with GH secretion and food intake in the sheep.

Grouselle Dominique, * Chaillou Elodie, *Caraty Alain, Bluet-Pajot Marie-Therese, Zizzari Philippe, *Tillet Yves, Epelbaum Jacques.

Addresses : UMR. 894 INSERM ; Centre de Psychiatrie \& Neuroscience, Faculté de Médecine, Université Paris Descartes; IFR Broca-Ste Anne, 75014, Paris , France, \& *INRA UMR 6175 PRC, IFR135, 37380, Nouzilly, France.

Corresponding author : J. Epelbaum UMR. 549 INSERM ; Faculté de MédecineUniversité-Paris-Descartes; IFR Broca-Ste Anne, 2ter rue d'Alésia, 75014, Paris France.

Tel: 3314078 9282; Fax: 33145807293

e-mail: jacques.epelbaum@broca.inserm.fr

Short title : ghrelin, GH \& feeding in sheep.

Key words : plasma, CSF, pulsatile patterns.

Elodie Chaillou and Dominique Grouselle contributed equally to this work. 


\section{ABSTRACT}

As in other species, exogenous administration of ghrelin, an endogenous ligand for the GH secretagogue receptors can stimulates feeding behaviour and GH secretion in the sheep. However the importance of endogenous ghrelin for these two functions as well as its central or peripheral origin remained to be established. In this study, CSF ghrelin concentrations were measured in five anoestrous ewes and found to be more than 1000-fold lower than circulating plasma levels, in keeping with the even lower concentration in hypothalamic as compared to abomasum tissue extracts. CSF and plasma ghrelin levels were measured every 10 minutes over a 6 hours sampling period in 5 unanesthetised ovariectomised-estradiol implanted ewes. Mean CSF ghrelin concentrations were 1400-fold lower than circulating plasma levels. Cluster analysis indicated that CSF ghrelin levels were markedly pulsatile with a greater number of peaks than plasma ghrelin. Pulsatility parameters were closer for GH and CSF ghrelin than between $\mathrm{GH}$ and plasma ghrelin. Plasma ghrelin and GH levels were significantly correlated in three out of five ewes but CSF ghrelin and GH in one ewe only. Half of the CSF ghrelin episodes were preceded by a ghrelin peak in plasma with a 22 min delay. Cross-correlations between plasma GH and plasma or CSF ghrelin did not reach significance but a trend towards cross-correlation was observed from 20 to 0 min between plasma and CSF ghrelin. At 09h00, when food was returned to ewes, voluntary food intake did not elicit a consistent change in plasma or CSF ghrelin levels. In contrast, a peripheral ghrelin injection (1 mg, i.v.) immediately stimulated food intake, feeding behaviour, and GH secretion. These effects were concomitant with a more than ten-fold increase in plasma ghrelin levels while CSF ghrelin values only doubled 40 to 50 minutes after the injection. This suggests that peripherally-injected ghrelin crosses the blood brain barrier but only in low amount 
and with relatively slow kinetics when compared to its effects on GH release and food intake. Taken together, these results support the notion that, in the ovariectomised-oestradiol implanted sheep model, peripheral ghrelin injection rapidly induces GH secretion, food intake and feeding behaviour, probably by acting on GHS-R1 receptors located in brain regions in which the blood brain barrier is not complete such as, for instance, the arcuate nucleus. 


\section{INTRODUCTION}

Ghrelin, originally characterised from rat stomach as an endogenous ligand of the Growth-Hormone-Secretagogue Receptor subtype 1a (GHS-R1a) (1), rapidly attracted an enormous interest as the first peripheral orexigenic hormone $(2,3)$. Ghrelin and GHSR receptors are expressed in many peripheral tissues and areas of the central nervous system and ghrelin can exert several neuroendocrine, metabolic and non endocrine functions in addition to the stimulation of GH secretion and appetite (4). These include stimulation of energy metabolism and adipogenesis, of gastric motility and acid secretion, influence of pancreatic and other endocrine secretions, modulation of anxiety and sleep patterns, hemodynamic and cardiovascular actions. Circulating ghrelin is likely to be mostly derived from stomach and gastrointestinal tract enteroendocrine cells but different intrahypothalamic neuronal networks have been recently described in mouse (5) rat $(6,7)$ and sheep (8). Thus, the central or peripheral origin of the ghrelin involved in the release of $\mathrm{GH}$ and initiation of food intake remained to be established. The aim of this work was to study the dynamic concentration of plasma and CSF ghrelin in relation to spontaneous GH secretion and food intake, and after peripherally administration of ghrelin. We took advantage of the oestradiol-replaced ovariectomised sheep model on which serial sampling of blood and cerebrospinal fluid (CSF) can be obtained for several hours in conscious animals without any interfering effects due to blood loss, immobilization stress or steroid variations (9). Ghrelin concentrations in central and peripheral tissues of ewes were first defined. Thereafter, the patterns of endogenous ghrelin secretion were measured in CSF in the third ventricle and plasma either on the endogenous hormone or after administration of the exogenous peptide, in relation with GH secretion profiles, food intake and feeding behaviour. 


\section{MATERIAL \&METHODS}

\section{Animals}

Experiments were conducted using mature Ile de France ewes during the anestrous season. Animals were maintained under normal husbandry conditions at the INRA (Nouzilly, France) and all experimental procedures were performed in accordance with local animal regulation (Authorization $\mathrm{N}^{\circ}$ A 37801 at the French Ministry of Agriculture). Animal protocols were submitted to ethical approval of a local committee.

\section{Experiment I}

In a preliminary experiment, performed in anoestrus (March) ewes, ghrelin concentrations were measured in the brain and gut tissues of four adult ewes (Ile de France breed 5-9 years old, 40-60 kg weight). They were killed by exsanguination, between $9 \mathrm{~h} 00$ and $11 \mathrm{~h} 00 \mathrm{am}$, by a licensed butcher in an official slaughterhouse, located close to the building (less than 100 meters) where the animals were kept during the experiment. Gut and brain tissues were rapidly dissected [between 5 minutes (brain) and 15 minutes (gut) after the death of the animals]. The hypothalamus was divided into three parts, according to the sheep brain atlas (10): rostral (frontal planes, A33-A30), medial (A29-A26) and caudal (A25-A22), each tissue sample was $10 \mathrm{~mm}$ wide (5 mm each side of the sagittal plane) and $8 \mathrm{~mm}$ high from the ventral edge of the brain. Ghrelin was immediately extracted in boiling acetic acid 2M with P-hydroxymercuri-benzoic acid (PHMB, 1mM Sigma St Louis USA) for $10 \mathrm{~min}$ and homogenised. Proteins were assayed on the homogenate. Supernatants were lyophilised and stored at $-80^{\circ} \mathrm{C}$ until used. 


\section{Experiment II}

Five Ile de France ewes (2-3 years old, 50-60 kg weight) were used. Two months before the experiment, animals were ovariectomised, under deep anaesthesia (induced by pentobarbital $12,5 \mathrm{mg} / \mathrm{kg}$ and maintained by $3 \%$ isoflurane) and a silastic tubing, packed with $10 \mathrm{~mm}$ crystalline 17 ß-oestradiol, was inserted under the skin to produce a plasma level of the steroid of $1-2 \mathrm{pg} / \mathrm{ml}$ (11) to suppress endogenous steroid variations which could interfere with GH secretion. Simultaneously a third ventricle cannula was also implanted in the vicinity of the hypothalamic structures involved in energy metabolism regulation to collect cerebrospinal fluid (CSF) as previously reported $(9,12)$. Briefly, the head was positioned in a stereotaxic frame (la precision cinematographique, Paris, France) and a radio-opaque liquid was injected in the lateral ventricle. Frontal and lateral X-rays were then taken which gave specific landmarks of the ventricular system. From the X-rays, the cannula (made with a stainless steel luer-lock needle, od $1.2 \mathrm{~mm}$; id, $0.86 \mathrm{~mm}$, length $55 \mathrm{~mm}$, Elite, Paris, France) was aimed approximately $2 \mathrm{~mm}$ above the infundibular recess of the third ventricle. When the tip of the cannula entered the third ventricle, cerebrospinal fluid flowed freely back up the tube. After confirmation of the position of the cannula by a lateral X-ray, it was then fixed to the skull of the ewe with dental acrylic cement and closed by a plastic stopper.

On the day before sampling, a catheter (od, $2.1 \mathrm{~mm}$, Intraflon 2, Biotrol, Paris, France) was rapidly inserted into the jugular vein of the ewes. Animals were then placed in contiguous pens that prevented them from turning around, but allowed them to lie down and freely move forward or backward. Animals were also able to see and smell each other in order to avoid isolation stress. On the next day, a polyethylene catheter (od, $0.7 \mathrm{~mm}$; id, $0.3 \mathrm{~mm}$; Biotrol, Paris, France) was inserted inside the 
cannula and blocked with a stopper so that the tip (distal end) projected $0.5 \mathrm{~mm}$ beyond the end of the cannula. The proximal end of the same catheter was connected to a peristaltic pump (Minipuls 2, Gilson, Villier-le-Bel, France) and CSF was continuously withdrawn from the third ventricle (flow rate $3 \mu \mathrm{lmin}$ ) and collected. Integrated CSF samples were collected manually at ten minutes interval for six hours (8h30-14h30). Using the jugular catheter, blood samples were collected remotely without disturbing the animals, simultaneously to each CSF samples.

One hour after initiation of the collection, animals received their usual daily food intake, ie a condensed meal (300g of corn maize barley mixture) and 15 min later straw was given ad libitum. This diet provides $1800 \mathrm{kcal}$ of metabolisable energy, corresponding to $100 \%$ estimated maintenance energy requirements (INRA, 1989). In basal conditions, the condensed meal is totally eaten in $5 \mathrm{~min}$ or even less, then animals eat straw during the first 2 hours, drink water and then lie down and eat very little during the 4-5 following hours for rumination. On the consecutive day, an injection of ghrelin (Neomps, Strasbourg, France, $1 \mathrm{mg} / \mathrm{ml}$, iv) was given at $14 \mathrm{~h} 30$, during the rumination period, and blood and CSF samples were collected $30 \mathrm{~min}$ before the injection and one hour after the injection. Feeding behavior was roughly recorded before and after ghrelin administration by counting the percentage of animals eating between two blood/CSF sampling period (i.e. 30 min before ghrelin administration and one hour after ghrelin administration). Blood samples were collected in glass tubes containing EDTA $(1 \mathrm{mg} / \mathrm{ml})$ and PHMB $(1 \mathrm{mM}$, final concentration) and centrifuged $20 \mathrm{~min}$ at $3000 \mathrm{rpm}$. Plasma were stored at $-80^{\circ} \mathrm{C}$ until assays. CSF were collected in glass tubes containing PHMB (1mM final) and frozen at $-80^{\circ} \mathrm{C}$ until use. 


\section{Experiment III}

In experiment II, ghrelin appeared to increase food intake in all animals but as CSF and blood samples were simultaneously collected feeding behavior could not be clearly recorded. In order to get a better description of ghrelin effect on food intact, an additional experiment was performed a year later during the anoestrous season. Two days before the experiment, seven ovariectomised oestradiol-treated ewes (similar to animals used in Exp. II) were placed in contiguous pens in which they received their usual daily meal at 8:30 am (300g corn maize barley mixture) with free access to water and straw (placed in a plastic container). On the day of the experiment, the same feeding procedure was applied (daily meal at 8:30 am) and at 1:00 pm, the ewes received an injection of ghrelin $(1 \mathrm{mg} / \mathrm{ml}$, iv) or saline $(\mathrm{NaCl}, 9 \%)$ in a random order. Immediately after, the quantity of straw in each plastic container was weighted. On the following day, the same experiment was performed, ghrelin or saline injections being switched so that each animal could be its own control. Ewes were continuously filmed, without the presence of any observer, using a digital camera (Sony, Paris, France). After fifty minutes of recording, the camera was stopped and the remaining quantity of straw weighted. Three parameters were used to evaluate feeding behaviour: the time the animals spent the head in the straw container with mastication activity, the latency of this behaviour, and the number of times it was observed. In the same manner, the number of vocalizations and water intakes, and the time spent lying down were recorded. The duration of each behaviour was expressed as percentage of time by 5 -min periods.

\section{Assays.}


Tissue extracts, plasma and CSF were assayed by a competitive solid phase enzyme immunoassay using a rabbit polyclonal antibody raised against the 1-11 N-terminus $\mathrm{N}$-acylated fragment for acylated ghrelin (1). Sheep N-acylated ghrelin was used as standard and human N-acylated ghrelin (Neomps Strasbourg, France) coupled to acetyl-cholinesterase as tracer (Spibio, Montigny le Bretonneux, France). Antibodies were used at a final dilution of $10^{-7}$ and mixed with standard ghrelin or samples $24 \mathrm{~h}$ before adding the enzymatic tracer in order to optimize their binding capacity; detection range was between $10 \& 400 \mathrm{pg} / \mathrm{ml}$. Non-acylated rodent and human ghrelin, rodent preproghrelin 37-21, 80-97 and 102-117 and human, rat and sheep obestatin (Neomps Strasbourg, France) did not cross-react significantly in the assay (\% cross reactivity $<0.1 \%$ ). Serial dilutions of sheep plasma and tissues in assay buffer paralleled the standard curve (Figure 1). Out of ten consecutive assays, intra and inter-assay variabilities were 5 and $6 \%$.

Plasma were assayed for Ovine GH using NIDDK-oGH-I-5 as standard and NIDDKanti--oGH-3 antiserum. NIDDK-oGH-I-5 was iodinated with Chloramine $\mathrm{T}$ and purified on G 50 Sephadex column $(20$ x 0,9$)$ just before the radioimmunoassay. Sensitivity was $4-150 \mathrm{ng} / \mathrm{ml}$. All samples were assayed in the same assay. Intra-assay variability was $2.1 \%$.

Tissues proteins were assayed by the method of Bradford (Bio-Rad, München, Germany).

\section{-Statistical analysis:}

Ghrelin and GH pulse analysis was performed using the Cluster 8 program (9: Cluster analysis: a simple, versatile, and robust algorithm for endocrine pulse detection.) with the $\mathrm{t}$ value set to 2 to maintain false positive rates under $1 \%$. Number of points for a 
nadir were set to 1 and 2 respectively. This method (13) is largely insensitive to unstable baseline hormone variations and is not adversely affected by modifying pulse amplitude widths, or configurations within the endocrine series. Moreover, its simple statistical basis renders it minimally dependent on assumptions about rates of hormone secretion or debradation Approximative entropy (ApEn), a quantification of serial irregularity (14), was calculated using the MC-ApEn program using R-value set to 0.2 and number of MC cycle set to 1000 . These programs are available from : http://mljohnson.pharm.virginia.edu/home.html. Cross-correlations between plasma GH and plasma ghrelin or CSF ghrelin or between plasma and CSF ghrelin were performed according to Mulligan et al (13). Briefly, paired serial data were correlated at each of various time lag of interest ranging from 100 to +100 min. Cross correlation $r$ values were calculated in each subject at each of multiple time lags. Statistically significance were determined by converting individual $\mathrm{r}$ values to standard deviate scores ( $\mathrm{z}$ scores) by dividing each original $\mathrm{r}$ value by its corresponding standard deviation. The latter was determined by Monte Carlo estimations, in which the order of each values in each paired was shuffled 500 times and the corresponding $\mathrm{r}$ values was used to compute a corresponding $\mathrm{z}$ score. Correlations between plasma GH and plasma ghrelin or CSF ghrelin or between plasma and CSF ghrelin were evaluated statistically by the Kolmogorov-Smirnov test under the null hypothesis that $\mathrm{z}$ scores matching the individual $\mathrm{r}$ values at any given lag are randomly and normally distributed about a zero mean with unit standard deviation.

Values are given as means \pm SEM, and statistical analysis was performed by ANOVA and paired $t$ test using the JMP IN 5.1 software (SAS Institute Inc., Cary, NC). 


\section{RESULTS}

Tissue and biological fluid ghrelin levels. As shown on table 1, abomasum ghrelin contents were the highest, being almost thirty fold higher than in small intestine and more than five thousand fold higher than in adeno- or neuro-hypophysis, the anterior and medial hypothalamus, the caudal hypothalamus, mamillary bodies and above, being even lower. Ghrelin levels were not detectable in olfactory bulb, cortex, hippocampus and cerebellum.

Ghrelin levels were measurable in CSF while a control peptide, somatostatin, was not detectable (Grouselle et al, unpublished results). Ghrelin levels in CSF (mean daily average values \pm sem, $22 \pm 4 \mathrm{pg} / \mathrm{ml}, \mathrm{n}=5$ ) were more than a thousand times lower than in plasma $(30,646 \pm 3,476 \mathrm{pg} / \mathrm{ml})$.

Individual pulsatile profiles of ghrelin and GH secretion are illustrated on figure 2. Parameters of ghrelin secretion in CSF were compared by cluster analysis with those of ghrelin and GH in plasma (Table 2). The number of peak episodes, duration and the interval between peaks varied considerably amongst individual sheeps. They were different for plasma and CSF ghrelin, the latter being closer to GH values. ApEn values were similar for the three parameters. Eleven out of the 23 Ghrelin secretory episodes in plasma (48\%) were followed by a peak in CSF ghrelin (delay 21.8 \pm 5.9 $\min$ ) but the reverse was true for only 8 out of 24 peaks (33\%).

At the individual level, plasma and CSF ghrelin or plasma GH and CSF ghrelin concentrations were significantly correlated in one ewe out of 5 while plasma ghrelin and GH levels were significantly correlated in three out of five ewes. When all data from the 5 ewes were pooled, the highest correlation was found for plasma ghrelin and GH (r2=0.281, $\mathrm{p}<0.0001)$, followed by plasma and CSF ghrelin ( $\mathrm{r} 2=0.173$, $\mathrm{p}<0,0001)$ and CSF ghrelin and plasma GH $(\mathrm{r} 2=0.123, \mathrm{p}<0.0001)$ (figure 3). 
However, cross-correlations between plasma GH and plasma or CSF ghrelin did not reach significance (figure $4 \mathrm{~A}$ et $\mathrm{B}$ ). A trend towards cross-correlation was observed from 20 to 0 min between plasma and CSF ghrelin (figure 4C).

\section{Kinetics of ghrelin injection effects on plasma GH and ghrelin levels, CSF ghrelin levels and food intake.}

No consistent change in plasma or CSF ghrelin occurred when food was reinstalled in the morning (ie 18h after former removal of food from the animals) prior to ghrelin or saline injections.

Following i.v. injection of $1 \mathrm{mg}$ ovine ghrelin, plasma GH levels immediately increased and remained elevated until the end of the sampling period (figure 5A). Plasma ghrelin also increased immediately after the injection, up to $200 \mathrm{ng} / \mathrm{ml}$, and returned to baseline in 45 minutes. In contrast, CSF levels were only increased twofold, reaching a maximum 55 minutes after the injection (figure 5B). Administration of ghrelin induced also a rapid food intake and GH stimulation, beginning 5 to $10 \mathrm{~min}$ following the injection, and lasting for 30-40 minutes (figure 5A and 5C). Food intake at this time of the day is unusual because it is the period of rumination as observed for the same animals the day before. A small increase in food intake was also observed 40 to 50 minutes after ghrelin injection when the peptide concentration reached its highest level into the CSF but GH concentrations had not returned to baseline levels (figure 5C).

\section{Effects of ghrelin injection on feeding behaviour.}

Fifty-five min after ghrelin administration, the cumulative food intake (Fig. 6a) was greater $(\mathrm{p}<0.001)(60.7 \pm 2.9 \mathrm{~g})$ than after saline injection $(4.2 \pm 2.97 \mathrm{~g})$. Ewes put 
their heads in the straw with a mastication activity significantly $(p<0.01$, Fig. 6b) quicker after ghrelin $(3.86 \pm 1.96 \mathrm{~min})$ than saline $(10.83 \pm 1.88 \mathrm{~min})$ injections. Moreover, ewes spent more than twenty percent of the time masticating, with their head in the straw, during the 55-min following ghrelin administration (Fig. 6c). The percentage of time spent lying down (Fig. 6d) or the number of vocalizations and water intakes (data not shown) were the same in the ghrelin- or saline-injected animals.

\section{DISCUSSION}

The main findings of the present study is that, in ovariectomised oestradiol-implanted ewes, 1) endogenous CSF ghrelin levels display pulsatile variations 2) plasma ghrelin and GH seem more significantly correlated than CSF ghrelin and GH, 3) Voluntary food intake is not strictly related to spontaneous changes in ghrelin levels either in the CSF or in the plasma, and 4) peripherally injected ghrelin does cross the blood brain barrier but only in small amount $(<1 / 1,000$ of the injected dose) and relatively slow kinetics when compared to its effects on GH release, food intake and feeding behaviour.

In intact anoestrous ewes, the highest levels of ghrelin were found in the abomasum and, to a lesser extent, small intestine while lower amounts were present in other parts of the digestive tract. Such observations are in agreement with previous immunohistochemical studies in sheep tissues indicating that ghrelin-immunoreactive cells are abundant in the oxyntic glands in the abomasum $(16,8)$, a structure from which digestive enzymes are released, corresponding to the stomach of monogastric animals. This is also in agreement with data obtained in monogastric species like rats 
or human in which ghrelin immunoreactive cells were described in the stomach (17). The main difference between sheep and rat or human tissues is found in the upper small intestine because only few immunoreactive cells were found in the two later species compared to the relatively high level measured in the sheep.

Ghrelin immunoreactivity was also visualised in hypothalamic regions such as the median eminence, arcuate and ventromedial nuclei as well as the ependymal lining of the third ventricle (8). Such immunohistochemical data only provide evidence of the presence of the peptide, not its secretion. Thus, CSF ghrelin concentrations are more than a thousand time lower than in the plasma. The difference is even higher for hypothalamic and gut ghrelin tissue concentrations. Moreover, it should be noted that the Ile de France breed has a fat phenotype and, in Corriedale ovariectomised ewes, plasma ghrelin concentrations is significantly greater in fat than in lean animals (18). Thus, the effects of adiposity remains to be tested on CSF ghrelin levels as yet.

In the ovariectomised oestradiol-treated ewe model (which may not be representative of the intact female or castrate or intact male animal), both CSF and plasma ghrelin secretions are pulsatile but the frequency of the episodes is higher in the CSF. Fortyeight $\%$ of CSF ghrelin episodes are preceded by 22 min by an episode in the plasma and there is an overall correlation between CSF and plasma ghrelin levels. Also, CSF ghrelin increased around 30 minutes after an iv ghrelin injection as confirmed by the cross-correlation measurements. Taken together, this indicates that peripheral ghrelin can either cross the blood brain barrier and enter the CSF or that it triggers some unknown mechanisms which induce local release in the CSF. Thus, the question of the origin of CSF ghrelin remains an open one. Thus, the comparison between 
iterative ghrelin measurements in plasma and CSF and GH in plasma is not sufficient to clearly assign a peripheral rather than a central origin for the peptide involved in the stimulation GH secretion. Concerning GH, The pulsatile pattern of secretion as observed herein, is closely reminiscent of the one previously reported in 5 ovariectomised ewes for which the GH pulse interval was 62 min. (19). In this previous study, a significant association occurred between GHRH in hypothalamic portal plasma and GH secretory pattern though not between GHRH and somatostatin or GH and somatostatin. Another study, conducted on 7 unanesthesised ewes, reported $33 \%$ of peak coincidence between somatostatin in hypothalamic portal plasma and GH secretory profiles (20). In the present work, we observed a significant cross-correlation between plasma ghrelin and GH in three out of five ovariectomised oestradiol-treated ewes but a correlation between plasma GH and CSF ghrelin was recorded in one ewe only. Moreover, delays of 35 minutes were observed between half of GH secretory episodes and plasma ghrelin peaks. This delay is compatible with the ghrelin kinetics to enter the CSF after intravenous injection. This may indicate that, in addition to GHRH/somatostatin interactions, endogenous peripheral ghrelin has to enter the brain, possibly at the level of the arcuate nucleus, to act on hypophysiotropic neurones involved in the pulsatile pattern of $\mathrm{GH}$ secretion. However, since $37 \%$ of plasma ghrelin episodes are not followed by a GH secretory peak, the stimulatory action of ghrelin on GH in sheep may depend on particular conditions, ie the neurohormonal tonus at a given time point $(12,21)$. However, crosscorrelation between plasma GH levels and plasma or CSF ghrelin concentrations did not reach significance. Thus, if endogenous peaks of ghrelin are unrelated to GH pulses but the overall concentrations is, this could indicate that ghrelin is supportive for GHRH and/or GH release in a tonic endogenous role. One way to verify that the 
apparent relationship between ghrelin and GH secretion is causal would be by central blockade of ghrelin receptors.

Concerning food intake, probably because of the food regimen of the animals, we did not observe in ovariectomised oestradiol-treated Ile de France ewes on their regular feeding schedule the transient ghrelin surge occuring just before feeding previously described in Suffolk rams on programmed feeding (22,23). However, $1 \mathrm{mg}$ ghrelin i.v. quickly stimulated food intake and feeding behaviour. The positive effect of ghrelin injections on feeding behaviour likely implies motivational processes that may depend on GHSR1A located not only in the hypothalamus but also in brain reward circuits (24). Peripheral ghrelin passage though the blood brain barrier has been demonstrated in mice, from blood to brain but also from brain to blood for human ghrelin (25). In this last study, mouse ghrelin, which differs from human ghrelin by two amino-acids only, was a much better substrate for the brain-to-blood than for the blood to brain transporter. According to the limited changes in CSF ghrelin as observed in our experiment, the passage from blood to brain of ovine ghrelin, which differs from human or mouse ghrelin by eight amino-acids mostly located in its C-terminal portion, also appears minimal. Nevertheless, the apparent cross-correlation between plasma and CSF ghrelin is not incompatible with the hypothesis that CSF levels are derived from the periphery. It should also be mentioned that the blood brain barrier comprises both a blood-CSF barrier (mainly choroids plexus) and a blood-brain barrier composed of endothelial cells of cerebral blood vessels in the mediobasal hypothalamus. Thus, ghrelin could enter MBH neurones and act before appearing in the CSF. At any rate, in ovariectomised Corriedale ewes, whether administered intracerebroventricularly or iv, ghrelin up to $100 \mu \mathrm{g}$ did not affect voluntary food 
intake (26). In contrast, even lower concentrations were readily effective on GH secretion. Taken together with our data and those of Sugino et al (17), these findings may indicate that ghrelin is more potent to stimulate GH secretion than food intake in ovariectomised oestradiol-treated female ewes but that a different situation occur in rams. Such a sex-difference has recently been reported in rats (27) At any rate, the present results confirm, for the ovariectomized oestradiol-implanted sheep model,, that peripheral ghrelin injection rapidly induces GH secretion, food intake and feeding behaviour, probably by acting first on GHS-R1 receptors located in brain regions in which the blood brain barrier is not complete such as, for instance, the arcuate nucleus.

\section{Acknowledgements}

We thank Dr M. Kojima for Ghrelin N-terminal antibody (\# 6-6) gift and NIH and Dr. A. Parlow for ovine GH radioimmunoassay reagents by National Hormone and Peptide Program.

\section{REFERENCES}

1. Kojima M, Hosoda H, Date Y, Nakazato M, Matsuo H, Kangawa K. Ghrelin is a growth-hormone-releasing acylated peptide from stomach. Nature 1999; 402:656-60. 
2. Smith RG, Jiang H, Sun Y. Developments in ghrelin biology and potential clinical relevance. Trends Endocrinol Metab 2005; 16:436-42.

3. Bluet-Pajot MT, Tolle V, Zizzari P, Tomasetto C, Grouselle D, Epelbaum J. [Ghrelin: a striking example of neuroendocrine peptide pleiotropy]. Med Sci (Paris) 2005; 21:715-21.

4. Kojima M, Ida T, Sato T. Structure of mammalian and nonmammalian ghrelins. Vitam Horm. 2008;77:31-46.

5. Cowley MA, Smith RG, Diano S, et al. The distribution and mechanism of action of ghrelin in the CNS demonstrates a novel hypothalamic circuit regulating energy homeostasis. Neuron 2003; 37:649-61.

6. Mondal MS, Date Y, Yamaguchi H, et al. Identification of ghrelin and its receptor in neurons of the rat arcuate nucleus. Regul Pept 2005; 126:55-9.

7. Sato T, Fukue Y, Teranishi H, Yoshida Y, Kojima M. Molecular forms of hypothalamic ghrelin and its regulation by fasting and 2-deoxy-d-glucose administration. Endocrinology 2005; 146:2510-6.

8. Miller DW, Harrison JL, Brown YA, et al. Immunohistochemical evidence for an endocrine/paracrine role for ghrelin in the reproductive tissues of sheep. Reprod Biol Endocrinol 2005; 3:60.

9. Skinner DC, Malpaux B, Delaleu B, Caraty A. Luteinizing hormone (LH)releasing hormone in third ventricular cerebrospinal fluid of the ewe: correlation with LH pulses and the LH surge . Endocrinology 1995; 136: 3230-7.

10. Richard P. Atlas stéréotaxique du cerveau de brebis (Préalpes du Sud). INRA edit. 1967.

11. Goodman RL, Pickover SM, Karsch FJ . Ovarian feedback control of folliclestimulating hormone in the ewe: evidence for selective suppression. 
Endocrinology. 1981;108: 772-7.

12. Tricoire H, Moller M, Chemineau P, Malpaux B. Origin of cerebrospinal fluid melatonin and possible function in the integration of photoperiod. Reprod Suppl 2003; 61:311-21.

13. Veldhuis JD, Johnson ML. Cluster analysis: a simple, versatile, and robust algorithm for endocrine pulse detection. Am J Physiol 1986; 250: E486-93.

14. Pincus SM. Irregularity and asynchrony in biological network signals. Methods Enzymol 321: 149-82.

15. Mulligan T, Iranmanesh A, Johnson ML, Straume M Veldhuis JD. Aging alters feed-forward and feedback linkages between LH and testosterone in healthy men. Am J Physiol 1997; 273 R1407-13.

16. Hayashida T, Murakami K, Mogi K, et al. Ghrelin in domestic animals: distribution in stomach and its possible role. Domest Anim Endocrinol 2001; 21:17-24.

17. Date Y, Kojima M, Hosoda H, et al. Ghrelin, a novel Growth HormoneReleasing acylated peptide, is synthesised in a distinct endocrine cell type in the Gastrointestinal Tracts of Rats and Humans. Endocrinology 2000; 141: 4255-61

18. Kurose Y, Iqbal J, Rao A, et al. Changes in expression of the genes for the leptin receptor and the growth hormone-releasing peptide/ghrelin receptor in the hypothalamic arcuate nucleus with long-term manipulation of adiposity by dietary means. J Neuroendocrinol 2005; 17:331-40.

19. Frohman LA, Downs TR, Clarke IJ, Thomas GB. Measurement of growth hormone-releasing hormone and somatostatin in hypothalamic-portal plasma 
of unanesthetized sheep. Spontaneous secretion and response to insulininduced hypoglycemia. J Clin Invest 1990; 86:17-24.

20. Veldhuis JD, Fletcher TP, Gatford KL, Egan AR, Clarke IJ. Hypophysealportal somatostatin (SRIH) and jugular venous growth hormone secretion in the conscious unrestrained ewe. Neuroendocrinology 2002; 75:83-91

21. Cataldi M, Magnan E, Guillaume V, Dutour A, Conte-Devolx B, Lombardi G, Oliver C. Relationship between hypophyseal portal GHRH and somatostatin and peripheral GH levels in the conscious sheep.J Endocrinol Invest. 1994 Oct;17(9):717-22.

22. Sugino T, Yamaura J, Yamagishi M, et al. A transient surge of ghrelin secretion before feeding is modified by different feeding regimens in sheep. Biochem Biophys Res Commun 2002; 298:785.-8.

23. Sugino T, Hasegawa Y, Kurose Y, Kojima M, Kangawa K, Terashima Y. Effects of ghrelin on food intake and neuroendocrine function in sheep. Anim Reprod Sci 2004; 82-83:183-94.

24. Jerlhag E, Egecioglu E, Dickson SL, Andersson M, Svensson L, Engel JA. Ghrelin stimulates locomotor activity and accumbal dopamine-overflow via central cholinergic systems in mice: implications for its involvement in brain rewarAddict Biol. 2006 Mar;11(1):45-54.

25. Banks WA, Tschop M, Robinson SM, Heiman ML. Extent and direction of ghrelin transport across the blood-brain barrier is determined by its unique primary structure. J Pharmacol Exp Ther 2002; 302:822-7.

26. Iqbal J, Kurose Y, Canny B, Clarke IJ. Effects of central infusion of ghrelin on food intake and plasma levels of growth hormone, luteinizing hormone, prolactin, and cortisol secretion in sheep. Endocrinology 2006; 147:510-9. 
27. Clegg DJ, Brown LM, Zigman JM, Kemp CJ, Strader AD, Benoit SC, Woods SC, Mangiaracina M, Geary N. Estradiol-dependent decrease in the orexigenic potency of ghrelin in female rats. Diabetes 2007; 56:1051-8.

\section{FIGURE LEGENDS}

Table 1: Comparison of gut and brain ghrelin contents.

Concentrations are expressed in pg of acylated ir-ghrelin / mg protein (means \pm sem, $n=4)$.

Table 2: Parameters of ghrelin secretion in CSF and plasma and GH in plasma by cluster and ApEn analysis.

Data are derived from 5 ovariectomised ewes sampled every 10 minutes for 6 hours. They are given in $\mathrm{ng} / \mathrm{ml}$ for $\mathrm{GH}$ and plasma ghrelin and in $\mathrm{pg} / \mathrm{ml}$ for CSF ghrelin.

a, aa, $\mathrm{p}<0.05$ and 0.01 vs CSF ghrelin; $\mathrm{b} \mathrm{p}<0.05$ vs GH.

Figure 1: Representative Ghrelin ELISA binding curves and sample parallelism.

Rostral hypothalamus (dotted line) and CSF (blue line) samples were diluted from 1/1 to $1 / 8$ fold. Plasma samples (red dots) were diluted from $1 / 50$ to $1 / 800$ fold. Small intestine (open black dots) samples were diluted from 1/800 to $1 / 12,800$.

Figure 2: Individual profiles of CSF and plasma acylated ir-ghrelin secretion as compared to GH secretory profiles in oestradiol-treated ovariectomised ewes.

Peaks as identified by cluster analysis, are indicated by an asterisk. Broken line indicates the time $(09 \mathrm{~h} 00)$ when a daily meal was provided to the animals. This meal is usually totally eaten in the first thirty minutes thereafter. No consistent change in 
the five ewes was observed for GH and plasma ghrelin or CSF ghrelin levels following this voluntary food intake.

Figure 3: Correlations between CSF and plasma acylated ir-ghrelin and plasma GH in individual samples from 5 oestradiol-treated ovariectomised ewes.

Figure 4: Median cross-correlation coefficient ( $\mathrm{r}$ values) between plasma $\mathrm{GH}$ and plasma ghrelin (A) or CSF ghrelin (B), or between plasma and CSF ghrelin (C). + : Kolmogorov-Smirnov one sample test using normal $(0.00,1.00)$ distribution : $\mathrm{P}<0.01$.

Figure 5: Effects of peripheral sheep acylated-ghrelin injections on the kinetics of plasma GH (A), plasma and CSF ghrelin (B) levels, and feeding behavior expressed as the percentage of animals spent the head in the straw container with mastication activity by $10 \mathrm{~min}$. periods (C).

Data are mean \pm sem of 6 ovariectomised oestradiol-treated ewes. Acylated-ghrelin (1 mg) was injected at $14 \mathrm{~h} 30$.

Figure 6: Effects of sheep acylated ghrelin peripheral injections on feeding behaviour of 7 ovariectomised oestradiol-treated ewes. Data (mean \pm SEM) are given as the quantity of straw eaten during the 55 minute period in saline (black bar) or ghrelin (white bar) treated animals (a), the latency to start to eat (b) and the percentage of time spent the head in the straw container (c) or spent lying down (d) by 5-minute periods. 
Figure 1

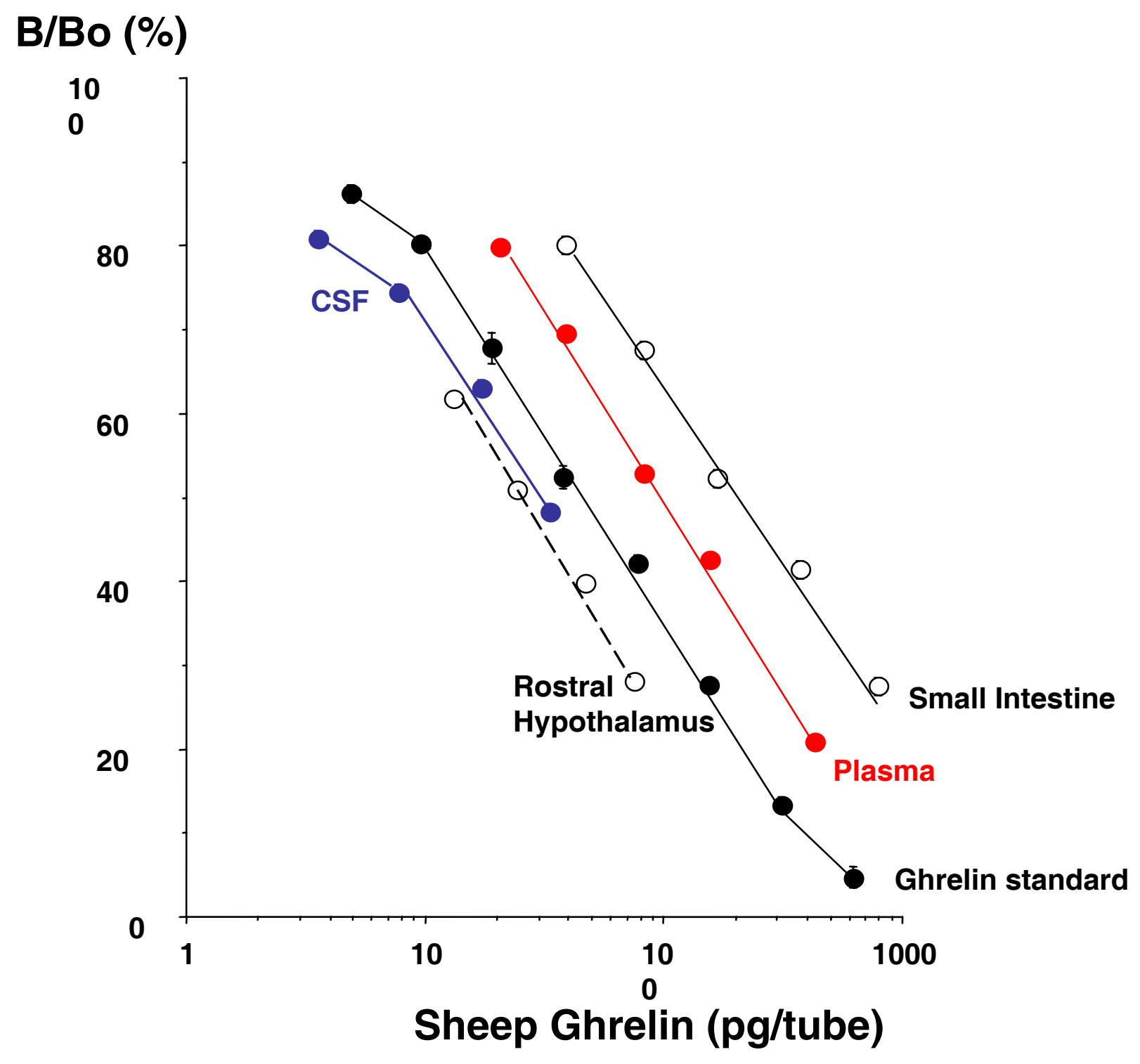




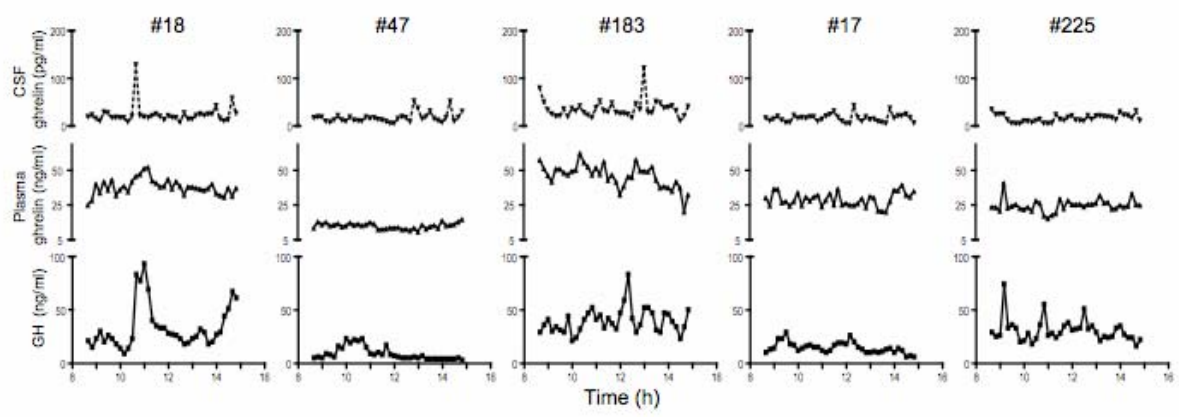

Figure 2 

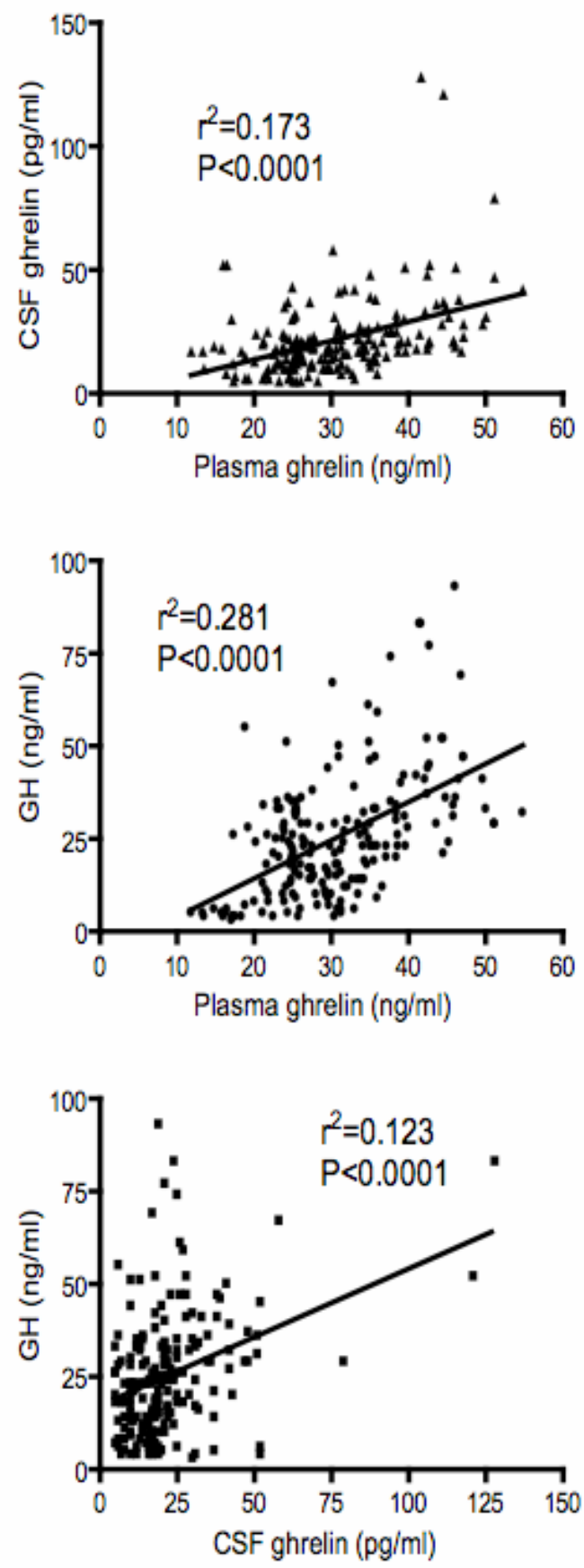

Figure 3 
A

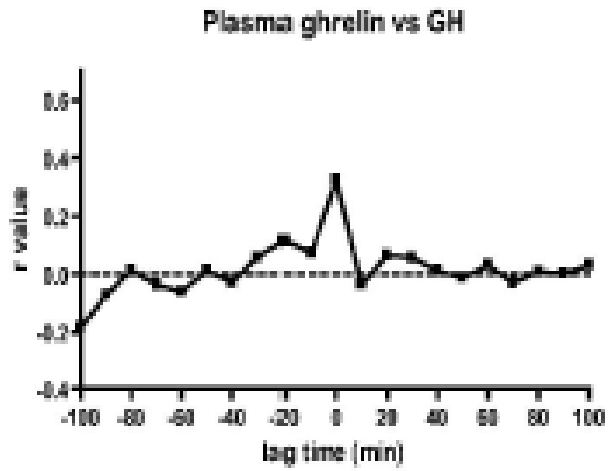

B

CSF ghrelin vs GH

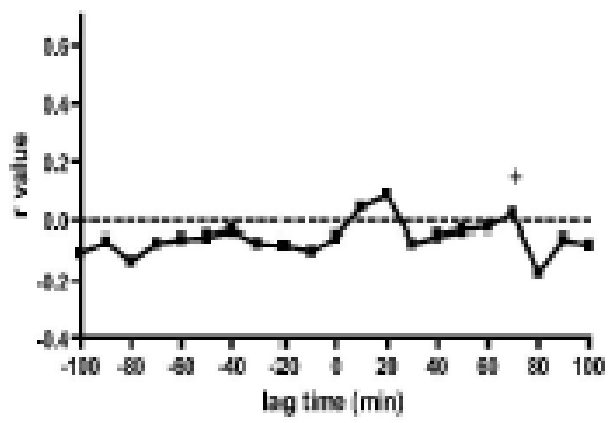

C plasma ghrelin vs CSF ghrelin

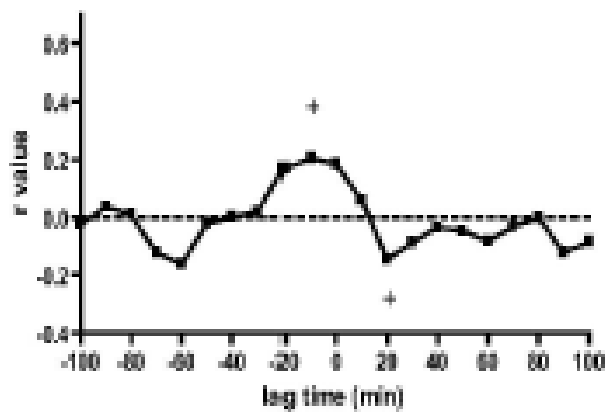

Figure 4

$83 \times 202 \mathrm{~mm}(600 \times 600 \mathrm{DPI})$ 


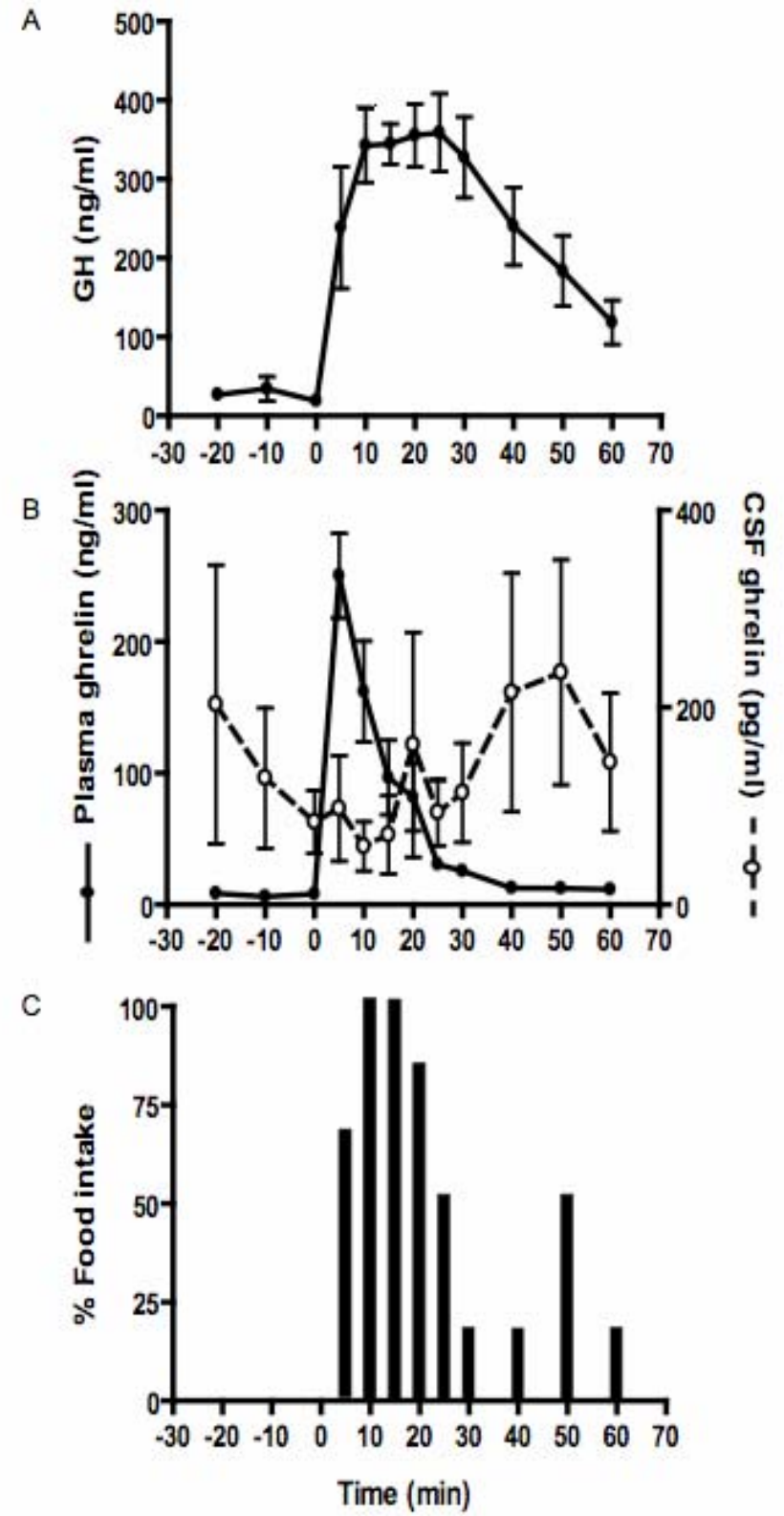

Figure 4 

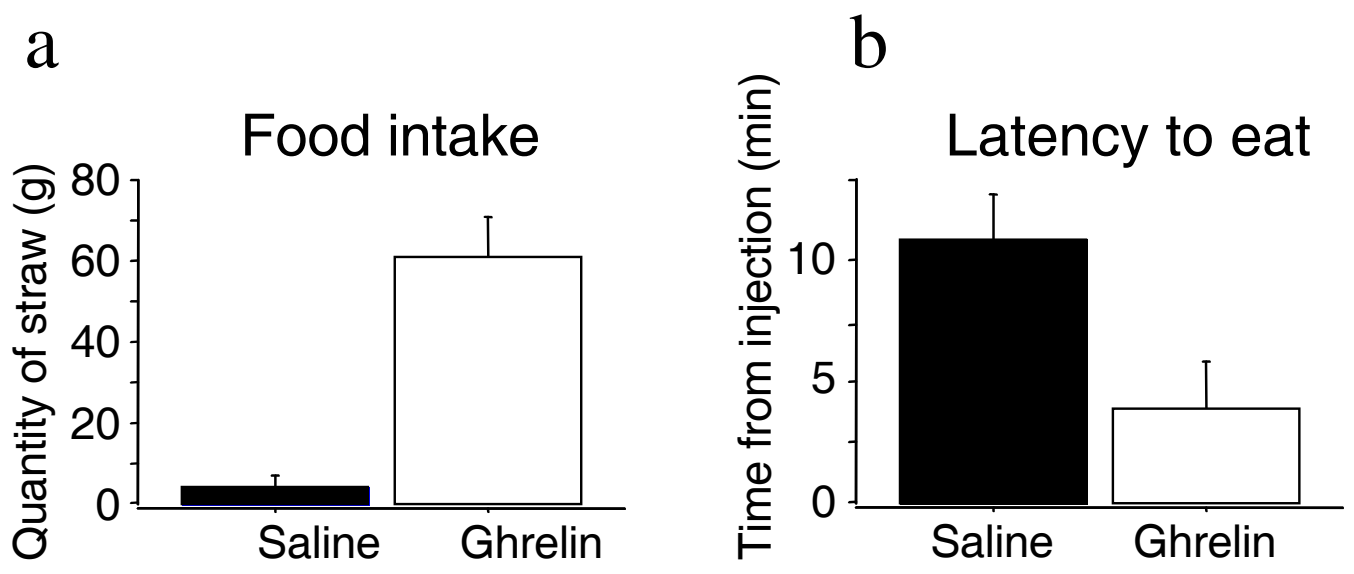

C Percentage of time spent with the head in the straw container
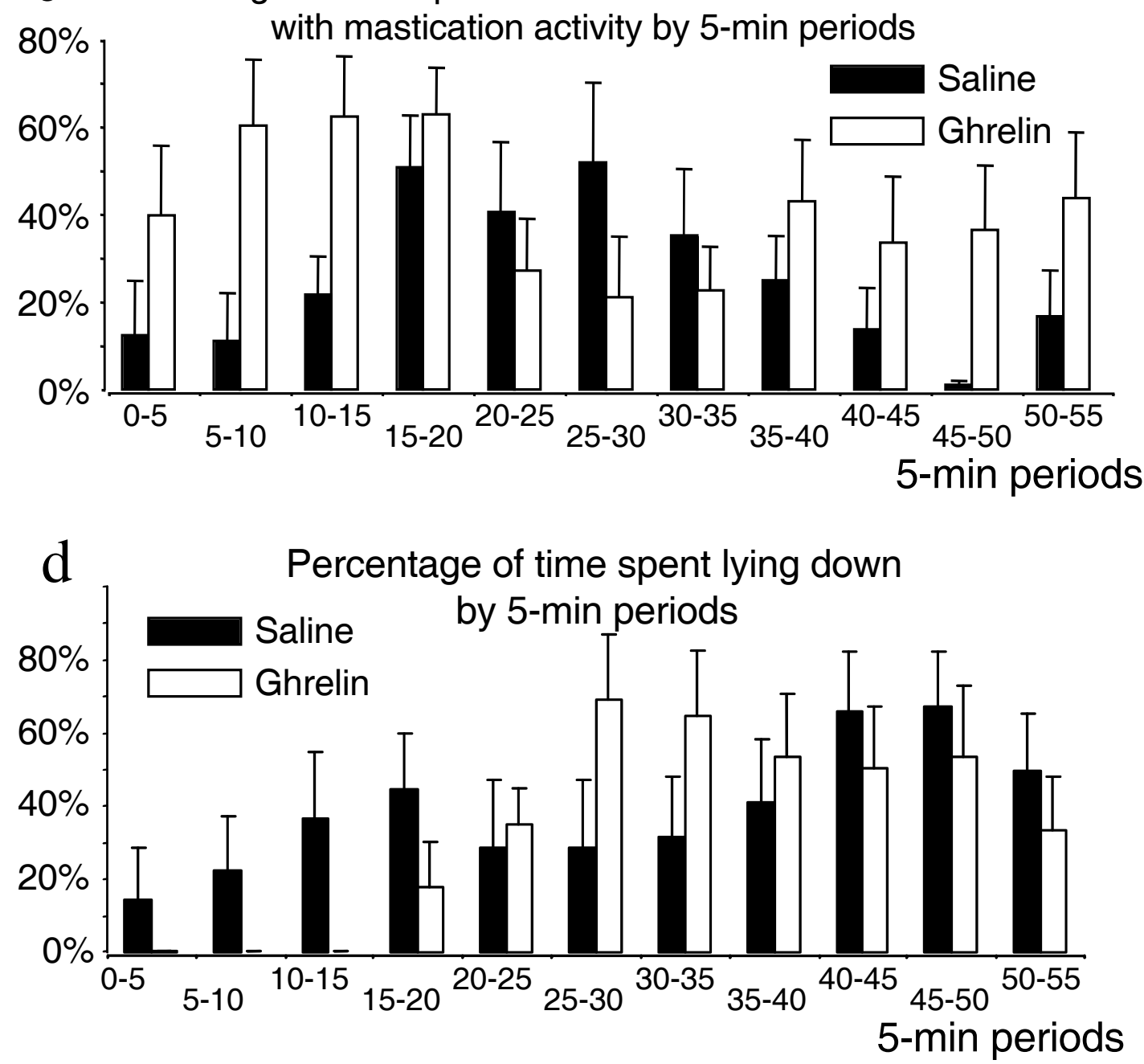

Figure 6 
Table 1: Tissue ghrelin concentrations

Data are mean \pm sem of 4 ewes.

\begin{tabular}{|l|r|}
\hline \multicolumn{1}{|c|}{$\begin{array}{c}\text { Tissues } \\
(\mathrm{n}=4)\end{array}$} & $\begin{array}{r}\text { Ghrelin concentrations } \\
(\mathrm{pg} / \mathrm{mg} \text { protein })\end{array}$ \\
\hline Rostral hypothalamus & $4 \pm 1$ \\
Median hypothalamus & $3 \pm 1$ \\
Caudal hypothalamus & $3 \pm 1$ \\
& \\
Neurohypophysis & $13 \pm 5$ \\
adenohypophysis & $23 \pm 2$ \\
& \\
Rumen & $10 \pm 1$ \\
Reticulum & $19 \pm 1$ \\
Omasum & $13 \pm 5$ \\
Abomasum & $112,030 \pm 8,870$ \\
Small intestine & $4,226 \pm 919$ \\
\hline
\end{tabular}

Table 2: Parameters of ghrelin secretion in CSF and plasma and GH in plasma by cluster and ApEn analysis.

Data are derived from 5 ovariectomised oestradiol-treated ewes sampled every 10 minutes for 6 hours. They are given in $\mathrm{ng} / \mathrm{ml}$ for $\mathrm{GH}$ and plasma ghrelin and in $\mathrm{pg} / \mathrm{ml}$ for CSF ghrelin.

a, aa, $\mathrm{p}<0.05$ and 0.01 vs CSF ghrelin; $\mathrm{b} \mathrm{p}<0.05$ vs $\mathrm{GH}$.

\begin{tabular}{|c|c|c|c|c|c|c|}
\hline $\mathrm{N}=5$ & $\begin{array}{c}\text { Peak } \\
\text { number }\end{array}$ & $\begin{array}{c}\text { Peak } \\
\text { Interval } \\
\text { (min) }\end{array}$ & $\begin{array}{c}\text { Peak } \\
\text { Duration } \\
\text { (min) }\end{array}$ & $\begin{array}{c}\text { Peak } \\
\text { amplitude }\end{array}$ & $\begin{array}{c}\text { Peak } \\
\text { nadir }\end{array}$ & ApEn \\
\hline $\begin{array}{c}\text { Ghrelin } \\
\begin{array}{c}\text { CSF } \\
\text { (pg/ml) }\end{array}\end{array}$ & $4.6 \pm 0.5$ & $58.0 \pm 5.6$ & $34.2 \pm 3.3$ & $38.2 \pm 8.5$ & $12.4 \pm 2.8$ & $1.150 \pm 0.014$ \\
\hline $\begin{array}{c}\text { Ghrelin } \\
\text { Plasma } \\
\text { (ng/ml) }\end{array}$ & $\begin{array}{c}3.2 \pm 0.2 \\
\mathrm{a}, \mathrm{b}\end{array}$ & $\begin{array}{c}102.6 \pm 7.6 \\
\text { aa }\end{array}$ & $\begin{array}{c}63.6 \pm 5.3 \\
\text { aa }\end{array}$ & $37.3 \pm 3.8$ & $26.5 \pm 3.1$ & $1.097 \pm 0.040$ \\
\hline $\begin{array}{c}\text { GH } \\
\text { lasma } \\
\text { (ng/ml) }\end{array}$ & $4.6 \pm 0.5$ & $76.0 \pm 13.7$ & $46.0 \pm 9.6$ & $38.4 \pm 8.0$ & $17.2 \pm 3.5$ & $1.022 \pm 0.099$ \\
\hline
\end{tabular}

